\title{
Inbreeding Depression for Global and Partial Economic Indexes, Production, Type, and Functional Traits
}

\author{
C. Croquet, ${ }^{\star} \dagger$ P. Mayeres, $\uparrow$ A. Gillon, $\dagger$ S. Vanderick, $\dagger$ and N. Gengler ${ }^{*} \dagger^{1}$ \\ *National Fund for Scientific Research, B-1000 Brussels, Belgium \\ †Animal Science Unit, Gembloux Agricultural University, B-5030 Gembloux, Belgium
}

\begin{abstract}
The objective of this research was to examine the effects of inbreeding in the population of Holstein cattle in the Walloon region of Belgium. The effects of inbreeding on the global economic index and its components were studied by using data from the genetic evaluations of February 2004 for production, somatic cell score (SCS), computed from somatic cell counts and type. Inbreeding coefficients for 956,516 animals were computed using a method that allows assigning an inbreeding coefficient to individuals without known parents. These coefficients were equal to the mean inbreeding coefficient of contemporary individuals with known parents. The significance of inbreeding effects on the different evaluated traits and on the different indexes were tested using a $t$-test comparing estimated standard errors and effects. The inbreeding effect was significantly different from zero for the vast majority of evaluated traits and for all of the indexes. Inbreeding had the greatest deleterious effects on production traits. Inbreeding decreased yield of milk, fat, and protein during a lactation by $19.68,0.96$, and $0.69 \mathrm{~kg}$, respectively, per each $1 \%$ increase in inbreeding. The regression coefficient of SCS per $1 \%$ increase in inbreeding was +0.005 SCS units. The inbreeding depression was thus relatively low for SCS, but inbred animals had higher SCS than non-inbred animals, indicating that inbred animals would be slightly more sensitive to mastitis than non-inbred animals. Estimates of inbreeding effects on evaluated type traits per $1 \%$ increase were small. The most strongly affected type traits were chest width, rear leg, and overall development on a standardized scale. For several type traits, particularly traits linked to the udder, the estimates suggested a favorable effect of inbreeding. The global economic index was depressed by around $6.13 €$ of lifetime profit per $1 \%$ increase in inbreeding for the Holstein animals in the Walloon region of Belgium.
\end{abstract}

Received December 23, 2004.

Accepted December 20, 2005.

${ }^{1}$ Corresponding author: gengler.n@fsagx.ac.be
Key words: incomplete pedigree, inbreeding, global economic index, genetic evaluation

\section{INTRODUCTION}

Voluntary inbreeding has been an empirical method to fix traits of interest for a long time. The best known example was the bull "Comet" born from mating of closely related individuals and one of the best known founders of the Shorthorn breed (Russell, 1947). Modern genetic selection programs based on mathematics, statistics, and computing tools identify families with superior genetic merit and reproductive technologies are used to disperse these genotypes throughout the population (Weigel, 2001). The best animals accumulate in pedigrees so that today it is practically impossible in a given dairy cattle breed to find animals without multiple genetic ties to certain individuals. Mating of related animals by definition leads to inbred offspring. One measure of inbreeding is the traditional inbreeding coefficient, which corresponds to half of the relationship between parents. Many methods can be used to compute inbreeding coefficient. Given the size of dairy cattle populations, the speed of computation matters. The method of Meuwissen and Luo (1992) based on a Cholesky decomposition is one of the fastest traditional, noniterative methods for computing inbreeding coefficients in large populations. All traditional methods assume that the inbreeding of animals with unknown parents equals zero. Obviously, these procedures underestimate inbreeding because all pedigrees eventually include unknown ancestors. VanRaden (1992) presented an extension to the traditional method, which assumes that the inbreeding coefficient of animals with unknown parents is equal to the average inbreeding of animals born in the same year. This method is obviously iterative because changes in inbreeding of ancestors affect descendants. VanRaden (1992) used this method successfully in the rather monolithic population of US Holsteins (Young et al., 1988; Young and Seykora, 1996) but the method has some limitations when there is gene flow among several related populations evolving differently; for example, in different countries. 
One of the main economic consequences of inbreeding is inbreeding depression, the reduction of the mean phenotypic value for economically important quantitative traits. The effect of inbreeding on mean phenotypic performance can be studied and accounted for by introduction of a linear regression term of phenotypic performances on inbreeding coefficient in the genetic evaluation model. Nonlinear effects may exist but were not the topic of this study.

The losses due to inbreeding reported in the literature differ in scale but mostly have the same direction. For production traits, they range from $-9.84 \mathrm{~kg}$ of milk to $-29.6 \mathrm{~kg}$ of milk, from $-0.55 \mathrm{~kg}$ of fat to $-1.08 \mathrm{~kg}$ of fat, and from $-0.80 \mathrm{~kg}$ of protein to $-0.97 \mathrm{~kg}$ of protein (Casanova et al., 1992; Miglior et al., 1992, 1995; Wiggans et al., 1995; Smith et al., 1998) per 1\% increase in inbreeding and for a lactation. Inbreeding may increase SCC (Miglior et al., 1995; Smith et al., 1998; Mrode et al., 2004); however, only a few studies tried to assess this. Miglior et al. (1995) showed that inbred animals could be inclined to develop mastitis. The effects of inbreeding on type traits were seldom reported and generally considered weak (Misztal et al., 1997; Smith et al., 1998). Traits most affected by inbreeding are often connected with reproductive performance (Miglior, 1994; Smith et al., 1998; Cassell et al., 2003). Impact of inbreeding on economic indexes has not been reported frequently. Smith et al. (1998) showed a loss of $\$ 22$ to $\$ 24$ lifetime net income (a parameter that estimates the economic impact of inbreeding) per $1 \%$ increase in inbreeding.

The aims of this study were to estimate the effect of inbreeding on production traits, type traits, and SCS, traits that were included in the calculation of breeding values for Walloon dairy cattle, and to combine these separate effects to estimate the effect of inbreeding on the current global economic index $(\mathbf{V} € \mathbf{G})$. Because the current index does not yet contain traits that are traditionally linked to high inbreeding depression (fertility and longevity), the results are only a lower bound of the total economic losses. Therefore, even if the results for those traits need to be added later, this study provides a framework to quantify the impact for further uses, such as in mating programs.

\section{MATERIALS AND METHODS}

\section{Pedigree File}

The pedigree file used for the official Walloon genetic evaluations of February 2004 was used for this study. This file contained information for 956,516 animals born between 1913 and 2004, the later birthdate is due to the fact that the Walloon genetic evaluations compute parent average for all recently born registered
Table 1. Distribution of the 551,070 Holstein animals present in the pedigree file according to their country of origin

\begin{tabular}{lrc}
\hline $\begin{array}{l}\text { Country } \\
\text { of origin }\end{array}$ & $\begin{array}{l}\text { No. of } \\
\text { animals }\end{array}$ & $\begin{array}{c}\text { Percent } \\
\text { of total }\end{array}$ \\
\hline Belgium & 488,003 & 88.6 \\
United States & 15,725 & 2.9 \\
Germany & 15,612 & 2.8 \\
France & 12,426 & 2.2 \\
Holland & 10,548 & 1.9 \\
Canada & 7,722 & 1.4 \\
Other countries & 1,034 & 0.2 \\
\hline
\end{tabular}

calves. In current procedures, North American Holstein ancestors are traced back as far as possible. The pedigree file was improved by estimating 61,501 unknown birth years and 12,354 unknown breed compositions from known birth years and breed compositions of ancestors or descendants. The vast majority of recently born animals were Holsteins; therefore, only results for this breed are shown. In total, the pedigree file contained 57.6\% Holsteins, $18.1 \%$ dual-purpose Belgian Blues, and $24.3 \%$ other breeds and crossbreeds.

The countries of origin of the Holstein animals in the pedigree file are presented in Table 1 . A relatively large proportion of the Holstein animals in the pedigree come from outside Belgium, mostly from the larger neighboring countries and from Canada and the United States. In recent years the proportion of animals with unknown ancestors has decreased sharply because of efforts to encourage calf registration. Table 2 shows the pedigree depth in Holstein cows with production records and their sires and maternal grand sires. Pedigree depth was expressed as equivalent complete generations of ancestors. Equivalent complete generations represent the logarithm in base 2 of the sum of the number of base ancestors (ancestors without known parents) over the whole pedigree of a given animal. This allowed us to access the average number of complete generations for all animals. The average number of known generations for cows with records born in 2000 reached 8.50 generations; for more recent birth years of sires (e.g., 1995) and maternal grand sires (e.g., 1992), the average numbers of known generations were equal to 10.06 and 9.35 , respectively.

\section{Data Used for Walloon Genetic Evaluation}

Data were provided by the Walloon Breeding Association (AWE), which manages performance recording data in the Walloon region of Belgium. The same data were used for the calculation of official February 2004 genetic evaluations and included milk production traits, type traits, and SCS. 
Table 2. Average and maximum number of complete generations for Holstein cows with production, their sires and maternal grand sires of these cows born since 1968 per year of birth of the cows, sires, or maternal grand sires

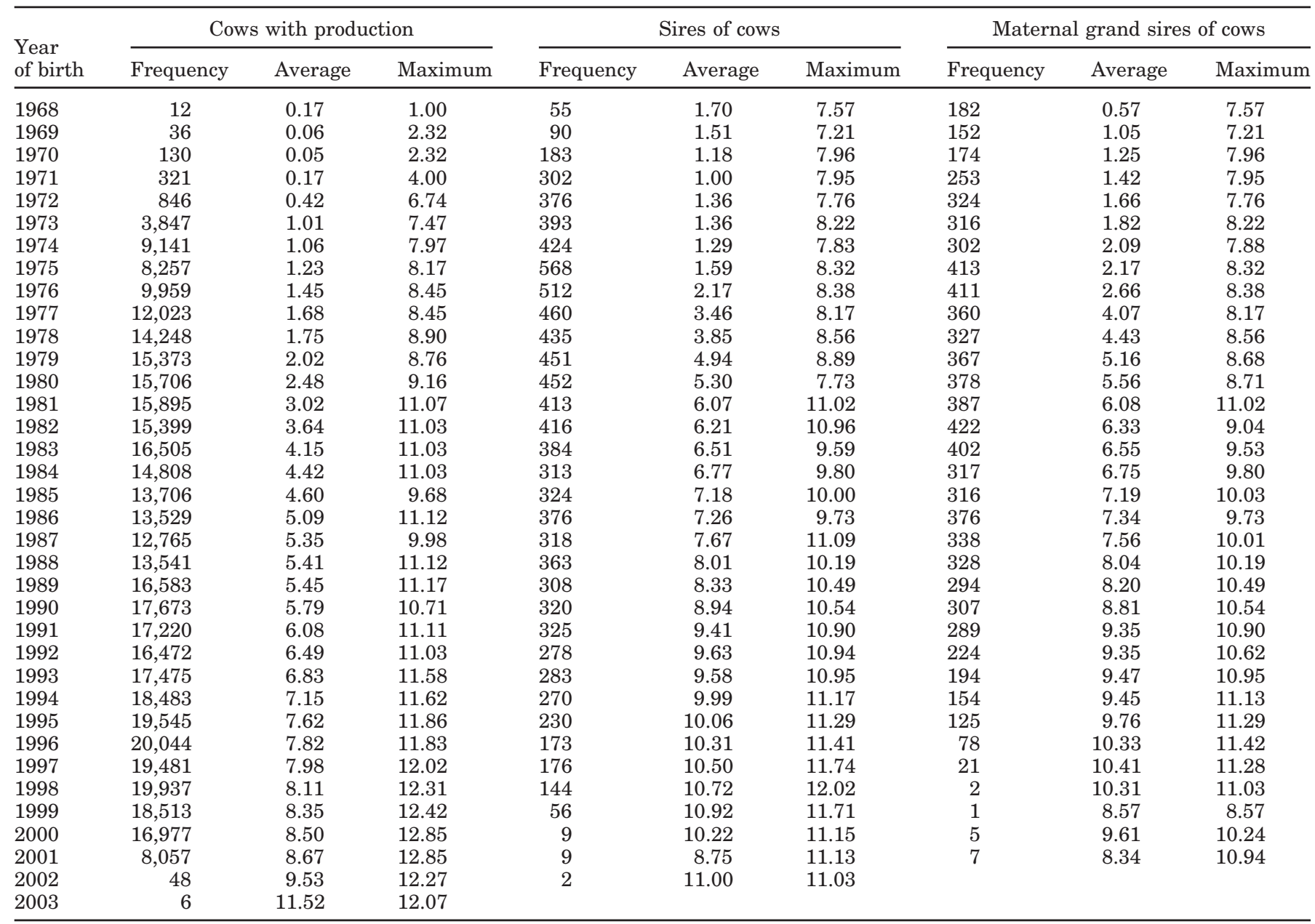

\section{Data for Production Traits and SCS}

For production traits and SCS, data were limited to first, second, and third parities. Data for yield traits consisted of 12,742,020 test-day records from 731,442 cows. The SCS were computed from SCC using the formula by Ali and Shook (1980): SCS $=\left[\log _{2}(\mathrm{SCC} /\right.$ 100,000)] +3 . Table 3 gives additional details of the production and SCS data for Holstein cows used in the routine run of February 2004.

\section{Data for Type Traits}

Data for type included 75,373 type records with a maximum of 33 observed type traits from 69,246 Holstein cows. Type traits could be scored during all lactations; the animal was required to have at least one score before the fourth calving. Table 4 gives more details for type traits used in the routine run of February 2004. Currently, a majority of first-calving cows and an increasing number of later calving cows are scored be-

Table 3. Data characteristics for production traits and SCS for first, second, and third parities of Holstein dairy population for Walloon genetic evaluations of February 2004

\begin{tabular}{|c|c|c|c|c|c|c|c|c|c|}
\hline & \multicolumn{3}{|c|}{ Lactation 1} & \multicolumn{3}{|c|}{ Lactation 2} & \multicolumn{3}{|c|}{ Lactation 3} \\
\hline 305-d Milk, kg & $3,442,996$ & $5,499.46$ & $1,925.55$ & $2,568,176$ & $6,257.44$ & $2,502.28$ & $1,831,624$ & $6,664.50$ & $2,690.82$ \\
\hline 305-d Protein, kg & $3,438,833$ & 179.66 & 60.82 & $2,566,196$ & 207.73 & 77.64 & $1,830,140$ & 219.45 & 82.47 \\
\hline SCS & $2,996,666$ & 2.94 & 1.58 & $2,253,150$ & 3.35 & 1.69 & $1,635,627$ & 3.68 & 1.74 \\
\hline
\end{tabular}


Table 4. Data characteristics for type traits in the Walloon Holstein dairy population for the genetic evaluations of February 2004

\begin{tabular}{lccc}
\hline Trait & Records & Average & SD \\
\hline Stature & 75,373 & 5.29 & 1.99 \\
Chest width & 64,507 & 5.16 & 1.22 \\
Body depth & 75,370 & 6.11 & 1.23 \\
Chest depth & 43,696 & 5.55 & 1.19 \\
Loin strength & 64,165 & 6.07 & 1.21 \\
Rump length & 54,902 & 5.44 & 1.06 \\
Rump angle & 75,368 & 4.63 & 1.20 \\
Hips width & 54,900 & 5.70 & 1.29 \\
Rump width & 46,411 & 5.50 & 1.19 \\
Foot angle & 46,411 & 4.99 & 1.04 \\
Rear leg set & 75,351 & 5.58 & 1.02 \\
Bone quality & 57,271 & 5.72 & 1.25 \\
Rear leg rear view & 33,360 & 4.57 & 1.16 \\
Udder balance & 57,616 & 5.05 & 0.95 \\
Udder depth & 68,473 & 4.89 & 1.24 \\
Teat placement side & 54,903 & 4.88 & 1.04 \\
Udder support & 64,496 & 5.96 & 1.45 \\
Udder texture & 46,412 & 6.06 & 1.09 \\
Fore udder & 64,498 & 5.61 & 1.32 \\
Front teat placement & 64,498 & 4.77 & 1.19 \\
Teat length & 75,358 & 5.05 & 1.08 \\
Rear udder height & 64,498 & 5.71 & 1.19 \\
Rear udder width & 53,300 & 5.20 & 1.24 \\
Rear teat placement & 57,611 & 3.52 & 1.19 \\
Angularity & 57,618 & 5.88 & 1.18 \\
Overall development & 29,341 & 80.91 & 5.12 \\
Overall rump & 29,342 & 82.17 & 4.02 \\
Overall feet and leg score & 29,341 & 80.50 & 3.62 \\
Overall udder score & 29,341 & 81.57 & 2.91 \\
Overall fore udder & 29,342 & 81.57 & 3.60 \\
Overall rear udder & 29,342 & 81.40 & 3.23 \\
Overall dairy trait & 29,341 & 81.45 & 4.04 \\
Overall conformation score & 29,341 & 80.58 & 2.59 \\
\hline & & &
\end{tabular}

cause the linear scores are used in a computerized mating program. Therefore, the subset of classified animals represents a relatively large proportion of the animals with production records.

\section{Models}

Models used in this study were the same models used in the current Walloon genetic evaluations for production and type traits and for SCS.

Current Genetic Model for Production Traits. A multilactation, multitrait random regression test-day model (RRTDM) is used in the Walloon region of Belgium. The model used currently can be written as

$$
\mathbf{y}=\mathbf{X b}+\mathbf{Q}(\mathbf{W h}+\mathbf{Z} \mathbf{a}+\mathbf{Z} \mathbf{p})+\mathbf{e}
$$

where $\mathbf{y}$ is a vector of precorrected milk, fat, and protein test-day records; $\mathbf{b}$ is a vector of fixed effects (herd $\times$ test date, stage of lactation, stage of lactation $\times$ age at calving $\times$ season of calving, gestation stage); $\mathbf{h}$ is a vector of herd $\times$ period of calving random regression coefficients; $\mathbf{a}$ is a vector of additive genetic random regression coefficients; $\mathbf{p}$ is a vector of permanent environmental random regression coefficients; $\mathbf{e}$ is a vector of random residuals; $\mathbf{X}, \mathbf{W}$, and $\mathbf{Z}$ are incidence matrices; and $\mathbf{Q}$ is the covariate matrix for second-order Legendre polynomials. The precorrection is applied to account for environmental effects of age within lactation $\times$ stage $\times$ breed classes. This process allowed correction for maturity differences within lactation according to breed composition; more details are provided in Auvray and Gengler (2002).

Current Genetic Model for SCS. The genetic evaluation model is a multilactation RRTDM similar to the one used for milk, fat, and protein. There are only 2 major modifications. First, no common herd environment effect is defined because previous research showed that this effect is very small for SCS and the model is only multilactation, not multitrait. Second, an iterative weighting of SCS records by a function expressing the probability of a mastitis event was introduced in the genetic evaluation model (Gengler and Mayeres, 2003). This modification is significant because it allows the transition from a purely descriptive evaluation of SCS to an evaluation that allows a better expression of the relationship between mastitis incidence and given test-day.

The RRTDM for SCS is written as

$$
\mathbf{y}=\mathbf{X b}+\mathbf{Q}(\mathbf{Z} \mathbf{p}+\mathbf{Z a})+\mathbf{e}
$$

where $\mathbf{y}$ is the vector of daily SCS, $\mathbf{b}$ is a vector of fixed effects (the same as for the production model), $\mathbf{p}$ is a vector of permanent environmental random regression coefficients, $\mathbf{a}$ is a vector of additive genetic random regression coefficients, and $\mathbf{e}$ is a vector of random residuals.

Current Genetic Model for Type Traits. The genetic evaluation model used for type traits is based on the one used for the genetic evaluation of non-Holstein breeds in the United States (Gengler et al., 1999, 2001a,b). This genetic evaluation method consists of 3 interdependent iterative systems that solve regular mixed model equations on a canonical scale, allowing the update of canonical traits to account for missing original traits. Integrated into this system is an adjustment for heterogeneous variance. The general model on a canonical scale can be written as

$$
\mathbf{y}_{\mathbf{Q}}=\mathbf{X h}+\mathbf{S s}+\mathbf{C c}+\mathbf{Z} \mathbf{p}+\mathbf{Z} \mathbf{a}+\mathbf{e}=\mathbf{M m}_{\mathbf{Q}}+\mathbf{e}
$$

where for a particular type trait, $\mathbf{y}_{\mathbf{Q}}$ is the vector of canonical type trait records adjusted for heterogeneity; $\mathbf{h}$ is the vector of fixed effects of herd, date scored, and parity (first or later) group (contemporary group); $\mathbf{s}$ is the vector of system specific fixed effects for age and 
lactation stage within parity group (first or later); $\mathbf{c}$ is the vector of classifier specific fixed effects for age and lactation stage; $\mathbf{p}$ is the vector of random effects of permanent environment; $\mathbf{a}$ is the vector of random additive genetic effects of animals and genetic groups; $\mathbf{X}$, $\mathbf{S}, \mathbf{C}$, and $\mathbf{Z}$ are the common incidence matrices for all traits that associate $\mathbf{h}, \mathbf{s}, \mathbf{c}, \mathbf{p}$, and $\mathbf{a}$, respectively, with $\mathbf{y}$; and $\mathbf{e}$ is the vector of random residual effects. Computation of canonical type-trait records adjusted for heterogeneity during iterations can be written as

$$
\mathbf{y}_{\mathbf{Q}}=\Gamma^{-1}\left[\mathbf{Q}_{1}(\mathbf{y}-\overline{\mathbf{y}})+\mathbf{Q}_{2} \boldsymbol{\Gamma} \mathbf{M} \hat{\mathbf{m}}_{\mathbf{Q}}\right]
$$

where $\Gamma$ is the multiplicative scaling matrix, its inverse being the adjustment matrix; $\overline{\mathbf{y}}$ is a vector containing the means of the traits; $\mathbf{Q}_{1}$ and $\mathbf{Q}_{2}$ are the transformation matrices defined as in Ducrocq and Besbes (1993) and obtained from the transformation matrix $\mathbf{Q}$; and $\hat{\mathbf{m}}_{\mathbf{Q}}$ are the current solutions on a canonical scale. More details can be found in Gengler et al. (2001c).

Partial and Global Economic Indexes. Theses indexes are called V€G for the global economic index, partial economic index milk ( $\mathbf{V} \in \mathbf{L}$ ) for the milk production traits, partial economic index type $(\mathbf{V} € \mathbf{T})$ for the morphology traits, and partial economic index functionality $(\mathbf{V} € \mathbf{F})$ for the functional traits index, where $V € G$ is the sum of $\mathrm{V} € \mathrm{~L}, \mathrm{~V} € \mathrm{~T}$, and $\mathrm{V} € \mathrm{~F}$. Currently, the $\mathrm{V} € \mathrm{~L}$ contains milk, fat, and protein yields; the V€T contains 15 type traits; and the V€F contains only SCS. The partial index $\mathrm{V} € \mathrm{~T}$ is itself subdivided into 3 secondorder indexes: partial economic index udder $(\mathbf{V} € \mathbf{P})$ for the udder traits, partial economic index body $(\mathbf{V} € \mathbf{C})$ for the development and frame traits, and partial economic index feet and legs $(\mathbf{V} € \mathbf{M})$ for the feet and legs traits. All of these partial economic indexes can be considered as the economic value of one standardized unit of the underlying linear combination of traits (for milk, type, and functional traits) multiplied by the number of standardized units. The derivation and computations were done following the example given by VanRaden (2000). The only major change, beyond the adaptation of the profit function to our situation, was that the economic values of one standardized unit of the underlying linear combination of traits were obtained by multiple regression instead of taking partial derivatives. Normally, in deriving economic values often called "a" values, correlations among the evaluated traits should not matter, because these correlations should be used instead to solve for multitrait additive genetic values. Thus, the economic values should be partial derivatives of true profit with respect to the evaluated traits, and true profit included correlated, nonmeasured traits such as feed consumption (VanRaden, 2000). However, our objective was to obtain approximate " $b$ " values because
Table 5. Relative importance of the several partial index and traits on Walloon genetic evaluation

\begin{tabular}{|c|c|c|c|c|}
\hline \multirow[b]{2}{*}{ Partial index/trait } & \multirow[b]{2}{*}{ Coefficient } & \multirow[b]{2}{*}{ SD } & \multicolumn{2}{|c|}{$\begin{array}{l}\text { Relative importance } \\
(\%) \text { in }\end{array}$} \\
\hline & & & $\begin{array}{l}\text { Partial } \\
\text { index }\end{array}$ & $\mathrm{V} € \mathrm{G}^{1}$ \\
\hline \multicolumn{5}{|c|}{$\mathrm{V} € \mathrm{G}^{1}$} \\
\hline$V € L^{2}$ & 1.000 & 83.86 & 55 & 55.0 \\
\hline $\mathrm{V} € \mathrm{~T}^{3}$ & 1.000 & 9.20 & 9 & 9.0 \\
\hline \multirow{2}{*}{\multicolumn{5}{|c|}{${ }^{1.000} \mathrm{~V} € \mathrm{~L}^{2}$}} \\
\hline & & & & \\
\hline Milk (kg) & -0.065 & 525.00 & 20 & 11.0 \\
\hline Fat (kg) & 2.370 & 22.90 & 30 & 16.5 \\
\hline \multicolumn{5}{|c|}{${ }_{\mathrm{V} € \mathrm{~F}^{4}}^{5.430} 16.40$} \\
\hline $\operatorname{SCS}(-3)$ & -24.630 V€ & 0.37 & 100 & 9.0 \\
\hline $\mathrm{V} € \mathrm{M}^{5}$ & 1.000 & 27.58 & 35 & 12.6 \\
\hline$V € C^{6}$ & 1.000 & 13.62 & 17 & 6.3 \\
\hline $\mathrm{V} € \mathrm{P}^{7}$ & 1.000 & $\begin{array}{l}10.02 \\
37.85\end{array}$ & 48 & 17.1 \\
\hline \multicolumn{5}{|c|}{${\mathrm{V} € \mathrm{M}^{5}}^{51.80}$} \\
\hline Rear leg set & -1.920 & 1.00 & 8 & 1.0 \\
\hline Rear leg rear view & 4.320 & 1.00 & 18 & 2.2 \\
\hline \multirow{2}{*}{\multicolumn{5}{|c|}{${\mathrm{V} € \mathrm{C}^{6}}^{1.00}$}} \\
\hline & & & & \\
\hline Stature & 9.000 & 1.00 & 45 & 2.8 \\
\hline Chest width & 3.000 & 1.00 & 15 & 1.0 \\
\hline Body depth & 3.000 & 1.00 & 15 & 1.0 \\
\hline Angularity & -4.000 & 1.00 & 20 & 1.3 \\
\hline Rump width & 1.000 & 1.00 & 5 & 0.3 \\
\hline \multicolumn{5}{|c|}{$\mathrm{V} € \mathrm{P}^{7}$} \\
\hline Fore udder & 9.800 & 1.00 & 14 & 2.4 \\
\hline Rear udder height & 16.100 & 1.00 & 23 & 3.9 \\
\hline Udder support & 6.300 & 1.00 & 9 & 1.5 \\
\hline Udder depth & 16.100 & 1.00 & 23 & 3.9 \\
\hline Front teat placement & 2.800 & 1.00 & 4 & 0.7 \\
\hline Rear teat placement & 12.600 & 1.00 & 18 & 3.1 \\
\hline Teat length & -6.30 & 1.00 & 9 & 1.5 \\
\hline
\end{tabular}

${ }^{1} \mathrm{~V} € \mathrm{G}=$ Global economic index.

${ }^{2} \mathrm{~V} € \mathrm{~L}=$ Partial economic index milk.

${ }^{3} \mathrm{~V} € \mathrm{~T}=$ Partial economic index type.

${ }^{4} \mathrm{~V} € \mathrm{~F}=$ Partial economic index functionality.

${ }^{5} \mathrm{~V} € \mathrm{M}=$ Partial economic index feet and legs.

${ }^{6} \mathrm{~V} € \mathrm{C}=$ Partial economic index body.

${ }^{7} \mathrm{~V} € \mathrm{P}=$ Partial economic index udder.

our additive genetic values were not multitrait and several traits in the selection objective (e.g., longevity) were not yet evaluated. These approximate "b" values allow us to consider the linear combination of genetic values for the available traits as the best linear predictor of true profit.

These indexes provide a simple tool for the Walloon breeders to choose parents despite the presence of over 30 different evaluated traits. They embody their economic selection goal of overall profitability over the productive life, as well as its components. Table 5 gives the relative importance of these traits in the partial and the global economic indexes. 


\section{Estimation of Inbreeding Coefficient}

An inbreeding coefficient for each animal in the Walloon pedigree file was computed using an algorithm based on Meuwissen and Luo (1992). The original algorithm is fast for large populations but assigns estimated inbreeding coefficients of zero for animals without known parents. Introduction of relationships between genetic groups estimated by the method of Auvray et al. (2001) allowed estimation of inbreeding of these animals. The method of Auvray et al. (2001) is similar to that of VanRaden (1992). However, in their method, Auvray et al. (2001) allow an individual with unknown parents to be assigned phantom parents representing a genetic group. The method to estimate inbreeding of the individual with 1 or 2 missing parents used in this study was a simplified version of the method of Auvray et al. (2001) integrated into the Meuwissen and Luo (1992) algorithm. The estimated inbreeding coefficient of such an individual was equal to half of the average relationship between genetic groups of his phantom parents. The genetic groups were based on variables able to explain the gene composition and groups together animals that are expected to have similar inbreeding. The variables used in this study were sex, year of birth, breed, and country of origin. It has to be acknowledged that this method did not allow introduction of relationships among animals with unknown ancestors, in contrast to the original method of Auvray et al. (2001). Our method was intended as a replacement of current routine inbreeding methods and behaved as most methods used in routine. However, additional research improving current algorithms should focus on this issue and allow the computationally demanding method of Auvray et al. (2001) to be integrated into routine methods.

\section{Estimation of Inbreeding Depression}

A linear regression of phenotypic performance on inbreeding coefficient was added to the genetic evaluation models to estimate inbreeding depression for production traits, type traits, and SCS. Solutions were given per $1 \%$ increase of inbreeding.

\section{Calculation of Impact of Inbreeding on Walloon Genetic Evaluations}

The combination of the effects of inbreeding on separate traits in the Walloon genetic evaluations and use of weighting presented in Table 5 allowed estimation of effects of inbreeding on different partial indexes and the global economic index per $1 \%$ increase in inbreeding.

\section{Estimation of Standard Errors}

In many analyses using linear mixed models, no standard errors of solutions are obtained, because they are of secondary importance to obtaining predicted breeding values or estimating variance components. Knowing these standard errors is useful, however, as it allows the application of hypothesis tests. Even if exact knowledge of standard errors is impossible in large mixed models, there are methods to approximate them. The method used in this study was presented by Gengler and Croquet (2005) and based on a suggestion by VanVleck (1992). Harville (1979) presented a method called the mixed model conjugate normal equations based on a suggestion by Henderson (1974). The mixed model equations are usually expressed as

$$
\left(\begin{array}{l}
\mathbf{X}^{\prime} \mathbf{R}^{-1} \mathbf{X} \mathbf{X}^{\prime} \mathbf{R}^{-1} \mathbf{Z} \\
\mathbf{Z}^{\prime} \mathbf{R}^{-1} \mathbf{X} \mathbf{Z}^{\prime} \mathbf{R}^{-1} \mathbf{Z}+\mathbf{G}^{-\mathbf{1}}
\end{array}\right)\left(\begin{array}{l}
\hat{\boldsymbol{\beta}} \\
\hat{\mathbf{u}}
\end{array}\right)=\left(\begin{array}{l}
\mathbf{X}^{\prime} \mathbf{R}^{-1} \mathbf{y} \\
\mathbf{Z}^{\prime} \mathbf{R}^{-1} \mathbf{y}
\end{array}\right),
$$

where $\mathbf{y}$ is the vector of observations, $\boldsymbol{\beta}$ is the vector of fixed effects, $\mathbf{u}$ is the vector of random effect, $\mathbf{X}$ and $\mathbf{Z}$ are the incidence matrices linking $\mathbf{y}$ with $\boldsymbol{\beta}$ and $\mathbf{u}, \mathbf{e}$ is the vector of residuals, $\mathbf{R}=\mathrm{V}(\mathbf{e})$ and $\mathbf{G}=\mathrm{V}(\mathbf{u})$. The mixed model equations can be simplified as $\mathbf{C} \hat{\mathbf{s}}=\mathbf{r}$, with $\hat{\mathbf{s}}=\mathbf{C}^{-1} \mathbf{r}$, where $\mathbf{C}$ is the coefficient matrix, $\mathbf{s}$ is the solution vector (containing both $\boldsymbol{\beta}$ and $\mathbf{u}$ ), and $\mathbf{r}$ is the vector of right-hand-side (RHS). To test the significance of an estimable function of the elements of $\hat{\boldsymbol{\beta}}$, the error variances and the covariances of the different concerned fixed effects are needed. From the mixed model theory and under the hypothesis that $\mathbf{R}$ and $\mathbf{G}$ are known exactly

$$
\mathbf{V}\left(\begin{array}{c}
\hat{\boldsymbol{\beta}} \\
\hat{\mathbf{u}}-\mathbf{u}
\end{array}\right)=\mathbf{C}^{-1}=\left(\begin{array}{cc}
\mathbf{C}^{\beta \beta} & \mathbf{C}^{\beta \mathbf{u}} \\
\mathbf{C}^{\mathbf{u} \beta} & \mathbf{C}^{\mathbf{u u}}
\end{array}\right)
$$

A basic property of mixed models is that $\mathrm{V}(\hat{\boldsymbol{\beta}})=\mathbf{C}^{\beta \beta}$ so that $\mathrm{V}\left(\mathbf{k}^{\prime} \hat{\boldsymbol{\beta}}\right)=\mathbf{k}^{\prime} \mathrm{V}(\hat{\boldsymbol{\beta}}) \mathbf{k}=\mathbf{k}^{\prime} \mathbf{C}^{-1} \mathbf{k}$. However, $\mathbf{C}^{-1}$ is usually impossible to compute. The alternative method used replaced the RHS by a contrast vector $\mathbf{k}$ (contained only values 0 and one single 1 related to the fixed effect to test) and the vector $\mathbf{s}$ by the vector $\phi$ so that: $\phi=\mathbf{C}^{-}$ ${ }^{1} \mathbf{k}$. Then, after premultiplying $\phi$ by $\mathbf{k}^{\prime}$ we obtain $\mathbf{k}^{\prime} \phi=$ $\mathbf{k}^{\prime} \mathbf{C}^{-1} \mathbf{k}$, which is what is needed. The square root of $\mathbf{k}^{\prime} \mathbf{C}^{-1} \mathbf{k}$ gives the standard error associated with the determined fixed effect.

In our situation, a block $\mathbf{C}_{\mathrm{s}}^{\beta \beta}$ of $\mathbf{C}^{\beta \beta}$ was needed. Its elements were obtained by computing linear functions of element of $\mathbf{C}^{\beta \beta}$ and by backsolving to obtain the needed elements of the block. In matrix notation, let $\mathbf{K}$ be the coefficients of the linear functions and $\mathbf{D}$ a matrix containing the results of the linear functions obtained 


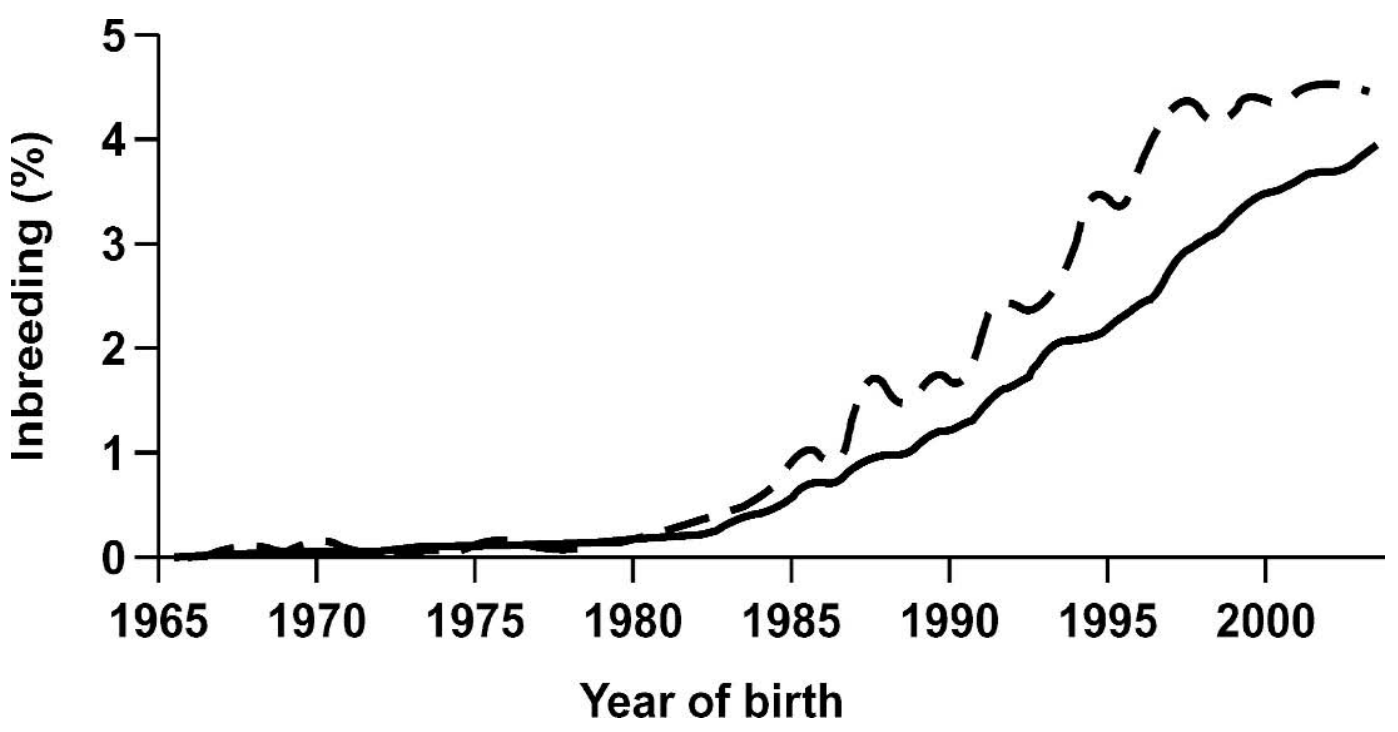

Figure 1. Average inbreeding (\%) by year of birth for Belgian Holstein males (---) and females (-) born between 1965 and 2003.

by computing $\mathbf{K}^{\prime} \mathbf{C}^{-1} \mathbf{K}$. The elements of the block were then obtained as $\mathbf{C}_{\mathrm{s}}^{\beta \beta}=\left(\mathbf{K}_{\mathrm{s}} \mathbf{K}_{\mathrm{s}}{ }^{\prime}\right)^{-1} \mathbf{K}_{\mathrm{s}} \mathbf{D} \mathbf{K}_{\mathrm{s}}{ }^{\prime}\left(\mathbf{K}_{\mathrm{s}} \mathbf{K}_{\mathrm{s}}{ }^{\prime}\right)^{-1}$ where $\mathbf{K}_{\mathrm{s}}$ is the part of $\mathbf{K}$ associated with the block $\mathbf{C}_{\mathrm{s}}^{\beta \beta}$.

Standard error for the average inbreeding depression estimated for a trait (milk, fat, protein, and SCS) on 3 lactations was obtained using a submatrix containing the error (co)variance for the estimated inbreeding depression on the trait for each of the 3 lactations. The computations for milk, fat, and protein were treated simultaneously. Standard errors associated with the inbreeding effect on partial and second-order economic indexes were estimated using error (co)variance submatrices for the inbreeding depression estimated for each trait used in the definition of each of these indexes. The standard error of the inbreeding effect on the global economic index (V€G) was estimated using selection index theory, because no error (co)variance matrix exists between the partial indexes ( $\mathrm{V} € \mathrm{~L}, \mathrm{~V} € \mathrm{~T}$, and $\mathrm{V} € \mathrm{~F})$.

A $t$-test was used in all cases to determine the significance of the different inbreeding effects:

$$
\mathrm{t}_{\mathrm{obs}}=\frac{\mathbf{k}^{\prime} \hat{\boldsymbol{\beta}}}{\sqrt{\mathbf{k}^{\prime} \mathbf{C}^{\beta \beta} \mathbf{k}}}
$$

The number of degrees of freedom of the $t$ variable can be approximated by N-rank $(\mathbf{X})$ under the hypothesis that $\mathbf{R}$ and $\mathbf{G}$ are known exactly (L. D. Van Vleck, Univ. Nebraska, Lincoln, personal communication).

\section{RESULTS AND DISCUSSION}

Results were computed for all breeds, but because the recent composition of the Walloon dairy population is $95 \%$ Holstein, we report only the results for this breed.

\section{Level of Inbreeding}

The mean inbreeding coefficient of Belgian Holstein females was $3.7 \%$ in 2003. Trends in mean inbreeding for Belgian Holstein males and females over the past $40 \mathrm{yr}$ are shown in Figure 1. Inbreeding of the Belgian Holstein cattle population has increased since 1965, but the increase was nonlinear over time and 2 periods for both females and males can be distinguished. Until the beginning of the $1980 \mathrm{~s}$, the mean level of inbreeding was small, with the annual average increase in mean inbreeding coefficient below $0.02 \%$. By the end of the 1990s, the mean inbreeding had become much larger, with annual average increases of $0.14 \%$ for females. The trend for males was similar, but less stable because of the relatively low number of animals.

The small amount of inbreeding observed before 1980 could be explained by different hypothesis. First, Belgian breeders were at that time only at the beginning of the "Holsteinization" process. Therefore, the animals during this period were Holstein crossbreds rather than purebred animals. Also, as shown in other studies, the general level of inbreeding was quite low in Holsteins compared with that seen today.

\section{Inbreeding Depression}

Tables 6,7 , and 8 present effects of a $1 \%$ increase in inbreeding on the different traits evaluated in the Walloon region of Belgium. Each of these effects is presented with its standard error and its significance. 
Table 6. Means estimates of inbreeding depression, associated standard errors and significance of inbreeding effects for yield traits per $1 \%$ increase in inbreeding during the first 3 parities of Holstein cows

\begin{tabular}{llll}
\hline & \multicolumn{3}{c}{ Losses of production per 1\% increase in inbreeding } \\
\cline { 2 - 5 } & $305-\mathrm{d}$ & $305-\mathrm{d}$ & 305-d \\
Lactation & Milk, kg & Fat, kg & Protein, kg \\
\hline 1 & $-18.81 \pm 0.87^{* * *}$ & $-0.91 \pm 0.04^{* * *}$ & $-0.65 \pm 0.03^{* * *}$ \\
2 & $-20.57 \pm 1.14^{* * *}$ & $-0.99 \pm 0.05^{* * *}$ & $-0.75 \pm 0.05^{* * *}$ \\
3 & $-19.67 \pm 1.40^{* * *}$ & $-0.99 \pm 0.06^{* * *}$ & $-0.68 \pm 0.04^{* * *}$ \\
Average & $-19.68 \pm 0.93^{* * *}$ & $-0.96 \pm 0.04^{* * *}$ & $-0.69 \pm 0.03^{* * *}$ \\
\hline \multirow{2}{*}{$* * * P<0.0018}$. & &
\end{tabular}

Table 6 presents estimates of 305-d lactation losses for yield traits per cow and per $1 \%$ increase in inbreeding. All of the inbreeding effects shown in Table 6 are highly significant. However, the losses per lactation for milk yields caused by inbreeding estimated in this study were lower than values cited in the North American literature (Miglior et al., 1995; Wiggans et al., 1995; Smith et al., 1998). An explanation could be that the scale of inbreeding depression is not a constant value, but is relative to the mean production. In consequence, in less productive populations such as the Walloon Holstein cattle (Table 3) compared with North American Holsteins, one would also expect less inbreeding depression.

Effects of $1 \%$ increase in inbreeding on SCS are showed in Table 7. The inbreeding depression on SCS presented in Table 7 was relatively low, but, as for production traits, the estimated inbreeding depression was very highly significant for each of the 3 first lactations. This result was in accordance with literature (e.g., Miglior et al., 1995; Smith et al., 1998; Thompson et al., 2000). On average, inbred animals tended to have higher SCS than non-inbred animals; therefore, because SCS is a parameter related to mastitis events (Coffey et al., 1986; Emmanuelson et al., 1988; Lund et al., 1994), this may mean that inbred animals tend to be more sensitive to mastitis perhaps because of a weakening of the immune system due to inbreeding (Miglior et al., 1995). For Miglior et al. (1995), a reason that could explain the small magnitude of inbreeding

Table 7. Means estimates of inbreeding depression, associated standard errors, and significance of inbreeding effects for SCS per $1 \%$ increase in inbreeding during the first 3 parities of Holstein cows

\begin{tabular}{ll}
\hline Lactation & $\begin{array}{l}\text { Inbreeding depression } \\
\text { for SCS }\left(\times 10^{-4}\right)\end{array}$ \\
\hline 1 & $+49.42 \pm 10.34^{* * *}$ \\
2 & $+49.19 \pm 12.55^{* * *}$ \\
3 & $+57.51 \pm 14.51^{* * *}$ \\
Average & $+52.04 \pm 10.04^{* * *}$ \\
\hline
\end{tabular}

$* * * P<0.001$ depression for SCS is the small dominance variance for SCS. Another explanation is that inbreeding affects production negatively, but production and SCS are negatively correlated phenotypically, leading to a partial cancellation of potential negative direct effects of inbreeding on SCS.

Table 8 presents estimates of inbreeding depression on type traits per $1 \%$ increase in inbreeding expressed in standardized and nonstandardized units, the first being easier to interpret because they remain on the original scoring scale. The standardized units, however, are used in the computations of the indexes. Table 8 shows that estimates of inbreeding depression for type traits tended to be small for all evaluated traits and nonsignificant for some. In particular, in this study, inbreeding was found to have negligible effects on loin strength, rump angle, rear leg set, udder balance, udder texture, fore udder, rear udder height, rear teat placement, angularity, overall rump, overall fore udder, and the overall dairy trait. However, we see the expected, very highly significant, inbreeding effects on stature and other traits related to the general development and appearance of the animals. Therefore, inbred cows tend to be smaller than non-inbred cows. In general, the type traits most affected by inbreeding, on the nonstandardized scale, were overall development, overall conformation score, overall feet and leg score, overall rear udder, stature and body depth; the inbreeding effect for all of these traits being at least highly significant. For Misztal et al. (1997), the type traits most affected by inbreeding, also on a nonstandardized scale, were body depth, chest width, and stature. As for Misztal et al. (1997), the estimates were positive for several type traits, the largest being for udder depth. For SCS, small or favorable inbreeding effects on type traits could be associated with small dominance variances (Misztal et al., 1997) or with competing partial relationships with inbreeding effects on production. Also, morphologically superior animals that are related could be used preferentially in matings to improve the type of animals. A recent example is the bull Hanoverhill Starbuck in Canada who is voluntarily accumulated in the pedigrees of Canadian Holsteins (Van Doormaal et al., 2005). This practice is called linebreeding. Because of the best linear unbiased estimator (BLUE) property of our inbreeding depression estimates, no confounding should happen; however, as we regress on estimated inbreeding, the conditions for BLUE are not totally fulfilled, and we can, therefore, not totally exclude this hypothesis. Under the assumption that the estimates are not totally BLUE, we might underestimate the effect of inbreeding and in extreme situations, even estimate positive inbreeding depressions due to confusion of positive additive genetic effects and negative effects of in- 
Table 8. Means estimates of inbreeding depression, associated standard errors and significance of inbreeding effects for type traits per $1 \%$ increase in inbreeding on standardized and nonstandardized scales, standardization done as in the Walloon genetic evaluations of Holsteins

\begin{tabular}{|c|c|c|}
\hline \multirow[b]{2}{*}{ Trait } & \multicolumn{2}{|c|}{ Inbreeding depression per $1 \%$ increase in inbreeding $\left(\times 10^{-3}\right)$} \\
\hline & On a nonstandardized scale & On a standardized scale \\
\hline Stature & $-18.39 \pm 3.27^{* * *}$ & $-24.73 \pm 4.39 * * *$ \\
\hline Chest width & $-11.47 \pm 2.33^{* * *}$ & $-74.61 \pm 15.17 * * *$ \\
\hline Body depth & $-14.76 \pm 2.18^{* * *}$ & $-48.30 \pm 7.12^{* * *}$ \\
\hline Chest depth & $-10.69 \pm 2.28^{* * *}$ & $-41.30 \pm 8.81 * * *$ \\
\hline Loin strength & $-2.97 \pm 2.64^{\mathrm{NS}}$ & $-14.30 \pm 12.70^{\mathrm{NS}}$ \\
\hline Rump length & $-5.26 \pm 2.02 * *$ & $-28.79 \pm 11.03^{* *}$ \\
\hline Rump angle & $0.39 \pm 2.58^{\mathrm{NS}}$ & $1.09 \pm 7.18^{\mathrm{NS}}$ \\
\hline Hips width & $-10.00 \pm 2.29 * * *$ & $-43.97 \pm 10.07 * * *$ \\
\hline Rump width & $-7.73 \pm 2.56^{* *}$ & $-33.51 \pm 11.08^{* *}$ \\
\hline Foot angle & $-3.58 \pm 2.40 \dagger$ & $-47.58 \pm 31.90 \dagger$ \\
\hline Rear leg set & $2.20 \pm 2.15^{\mathrm{NS}}$ & $13.52 \pm 13.24^{\mathrm{NS}}$ \\
\hline Bone quality & $3.84 \pm 2.76 \dagger$ & $13.37 \pm 9.60 \dagger$ \\
\hline Rear leg rear view & $-6.76 \pm 3.20^{*}$ & $-62.20 \pm 29.42^{*}$ \\
\hline Udder balance & $-2.27 \pm 2.24^{\mathrm{NS}}$ & $-10.38 \pm 10.22^{\mathrm{NS}}$ \\
\hline Udder depth & $8.01 \pm 2.13^{* * *}$ & $30.65 \pm 8.13^{* * *}$ \\
\hline Teat placement side & $-5.50 \pm 2.37 *$ & $-28.07 \pm 12.12^{*}$ \\
\hline Udder support & $-4.06 \pm 3.15 \dagger$ & $-13.48 \pm 10.47 \dagger$ \\
\hline Udder texture & $-2.46 \pm 2.51^{\mathrm{NS}}$ & $-13.17 \pm 13.44^{\mathrm{NS}}$ \\
\hline Fore udder & $1.39 \pm 2.67^{\mathrm{NS}}$ & $4.96 \pm 9.53^{\mathrm{NS}}$ \\
\hline Front teat placement & $5.37 \pm 2.64^{*}$ & $16.05 \pm 7.90^{*}$ \\
\hline Teat length & $-4.04 \pm 2.38 * *$ & $-13.36 \pm 7.85^{* *}$ \\
\hline Rear udder height & $-0.95 \pm 2.29^{\mathrm{NS}}$ & $-3.48 \pm 8.40^{\mathrm{NS}}$ \\
\hline Rear udder width & $-5.96 \pm 2.46 * *$ & $-27.79 \pm 11.45^{* *}$ \\
\hline Rear teat placement & $0.33 \pm 2.60^{\mathrm{NS}}$ & $1.05 \pm 8.28^{\mathrm{NS}}$ \\
\hline Angularity & $0.65 \pm 2.53^{\mathrm{NS}}$ & $1.78 \pm 6.93^{\mathrm{NS}}$ \\
\hline Overall development & $-65.49 \pm 9.57^{* * *}$ & $-51.72 \pm 7.56^{* * *}$ \\
\hline Overall rump & $-2.66 \pm 10.67^{\mathrm{NS}}$ & $-3.94 \pm 15.82^{\mathrm{NS}}$ \\
\hline Overall feet and leg score & $-21.23 \pm 9.09 * *$ & $-48.59 \pm 20.81^{* *}$ \\
\hline Overall udder score & $-9.24 \pm 6.57 \dagger$ & $-15.20 \pm 10.81 \dagger$ \\
\hline Overall fore udder & $2.41 \pm 8.88^{\mathrm{NS}}$ & $+3.20 \pm 11.44^{\mathrm{NS}}$ \\
\hline Overall rear udder & $-18.07 \pm 7.15^{* *}$ & $-31.53 \pm 12.48^{* *}$ \\
\hline Overall dairy trait & $-5.21 \pm 8.26^{\mathrm{NS}}$ & $-5.02 \pm 7.96^{\mathrm{NS}}$ \\
\hline Overall conformation score & $-24.52 \pm 5.54^{* * *}$ & $-38.42 \pm 8.68^{* * *}$ \\
\hline
\end{tabular}

$\mathrm{NS}=$ nonsignificant; $\dagger P<0.10 ; * P<0.05 ; * * P<0.01 ; * * * P<0.001$.

breeding. This hypothesis may also explain positive values for effects of inbreeding on V€P shown in Table 9. This last result could also be an artifact of less milk production of inbred animals, which therefore have smaller, better looking udders. For the V€C and the $\mathrm{V} € \mathrm{M}$, however, inbreeding depressions remained negative, as expected.

Table 9 presents effects of inbreeding on the V€G and the different partial indexes used in the Walloon region of Belgium; results are presented with their standard errors and their significance. Table 9 shows that the inbreeding effect was at least highly significant for all of these indexes. The influence of inbreeding on $\mathrm{V} € \mathrm{~L}$ was $-4.77 €$, the largest of all the indexes. The inbreeding depression for $\mathrm{V} € \mathrm{~F}$ was rather low, as expected given the limited influence of inbreeding on SCS. The inbreeding depression for V€T was negative, despite a positive value for $\mathrm{V} € \mathrm{P}$.

In total, the loss resulting in a $1 \%$ increase in inbreeding on the V€G summed to $-6.13 €$. Obviously, this
Table 9. Effects of $1 \%$ increase in inbreeding on different partial index (first and second order) and global economic index presented with their standard errors and their significance

\begin{tabular}{|c|c|c|c|}
\hline \multicolumn{3}{|c|}{ Index } & \multirow[b]{2}{*}{$\begin{array}{l}€ \text { per } 1 \% \text { increase } \\
\text { in inbreeding }\end{array}$} \\
\hline Global & Partial & $\begin{array}{l}\text { Second-order } \\
\text { partial }\end{array}$ & \\
\hline $\mathrm{V} € \mathrm{G}^{1}$ & $\begin{array}{l}\mathrm{V} € \mathrm{~L}^{2} \\
\mathrm{~V} € \mathrm{~T}^{3}\end{array}$ & $\begin{array}{l}\mathrm{V} € \mathrm{P}^{4} \\
\mathrm{~V} € \mathrm{C}^{5} \\
\mathrm{~V} € \mathrm{M}^{6}\end{array}$ & $\begin{aligned} &-6.13 \pm 0.91^{* * *} \\
&-4.77 \pm 0.18^{* * *} \\
&-1.23 \pm 0.69^{* *} \\
& 0.54 \pm 0.32^{* *} \\
&-0.63 \pm 0.08^{* * *} \\
&-1.14 \pm 0.59^{* *} \\
&-0.13 \pm 0.02^{* * *}\end{aligned}$ \\
\hline
\end{tabular}

\footnotetext{
${ }^{1} \mathrm{~V} € \mathrm{G}=$ Global economic index.

${ }^{2} \mathrm{~V} € \mathrm{~L}=$ Partial economic index milk.

${ }^{3} \mathrm{~V} € \mathrm{~T}=$ Partial economic index type.

${ }^{4} \mathrm{~V} € \mathrm{M}=$ Partial economic index feet and legs.

${ }^{5} \mathrm{~V} € \mathrm{C}=$ Partial economic index body.

${ }^{6} \mathrm{~V} € \mathrm{P}=$ Partial economic index udder.

${ }^{7} \mathrm{~V} € \mathrm{~F}=$ Partial economic index functionality.

$* * P<0.01 ; * * * P<0.001$.
} 
result is an underestimation of the real economic impact because traits such as fertility, longevity, and health that are linked with high inbreeding depression are not yet accounted for in the V€G. However, this result also means that, given the current selection indices, if we choose between 2 bulls for a mate, every $1 \%$ difference in inbreeding in their offspring has to be compensated by $12.26 \mathrm{~V} € \mathrm{G}$ points. For example, if one bull creates $6 \%$ inbreeding, and the other $1 \%$, the difference the first one has to compensate is more than 61 V€G points. This small example also shows the important ranking differences that may occur when breeding values are adjusted for inbreeding. Given these facts and the unfavorable trend of inbreeding in the Holstein population, the United States recently decided to consider inbreeding both in the genetic evaluations and in the expression of breeding values or PTA (VanRaden and Tooker, 2004) using the methods developed by VanRaden and Smith (1999). This approach is necessary, because simply preventing inbred matings is only effective to decrease inbreeding coefficients in the short term; it hardly has an effect on effective population size and future genetic diversity.

\section{CONCLUSIONS}

Coefficients of inbreeding for animals in the Walloon pedigree file were computed using a method that used a fast algorithm for estimation of inbreeding coefficients for animals without known origins. The inbreeding trend over the past $40 \mathrm{yr}$ for Belgian Holsteins has gradually increased, similar to trends reported for Holsteins in other countries (e.g., Miglior, 1994; Kearney et al., 2004) and has accelerated in recent years. For 2003, the mean level of inbreeding of Belgian Holstein females was $3.7 \%$.

The effect of inbreeding was significantly different from zero for the vast majority of traits currently evaluated genetically, with the exception of some type traits, and for all of the indexes used in the Walloon region of Belgium. Inbreeding was found to have a deleterious effect on most of these traits.

The global economic index, which measures the expected lifetime economic profitability, showed that inbred animals have a lower value than the average of their parents. With a loss of $4.77 €$ per $1 \%$ increase in inbreeding, the $\mathrm{V} € \mathrm{~L}$ is the component of the global economic index most strongly affected by inbreeding. Results for type traits were less clear cut than for production, but still showed a loss of $1.23 €$ per $1 \%$ increase in inbreeding in $\mathrm{V} € \mathrm{~T}$. Inbreeding depression was rather low for $\mathrm{V} € \mathrm{~F}$, which is for the moment only based on SCS. Inbreeding depression on the global economic index was approximately $-6.13 €$ and thus appears relatively low but may still induce rerankings if considered in mating decisions.

In the future, this index will contain parameters as fertility, longevity, and health that are likely to be more sensitive to inbreeding, and a revised V€G should thus be more profoundly affected by inbreeding. The recognition of the potential related animals before a mating decision can minimize inbreeding and the associated losses.

\section{ACKNOWLEDGMENTS}

Coraline Croquet, who is a Research Fellow, and Nicolas Gengler, who is a Research Associate of the National Fund for Scientific Research (Brussels, Belgium), both acknowledge their support. Additional support was provided through Grant 2.4507.02 F (2) of the National Fund for Scientific Research. The authors gratefully acknowledged the support of the Walloon Breeding Association (AWE) and the Walloon regional Ministry of Agriculture (Projects: RW1009, D31-1039) and manuscript review by G. R. Wiggans and P. M. VanRaden (Animal Improvement Programs Laboratory, ARS, USDA, Beltsville, MD).

\section{REFERENCES}

Ali, A. K. A., and G. E. Shook. 1980. An optimum transformation for somatic cell concentration in milk. J. Dairy Sci. 63:487-490.

Auvray, B., and N. Gengler. 2002. Feasibility of a Walloon test-day model and study of its potential as tool for selection and management. http://www-interbull.slu.se/bulletins/bulletin29/ Auvray.pdf Interbull Bull. 29:123-127.

Auvray, B., G. R. Wiggans, F. Miglior, and N. Gengler. 2001. Method to establish average relationships among Holstein bull populations over time. J. Dairy Sci. 84(Suppl. 1):215. (Abstr.)

Casanova, L., C. Hagger, N. Kuenzi, and M. Schneeberger. 1992. Inbreeding in Swiss Braunvieh and its influence on breeding values predicted from a repeatability animal model. J. Dairy Sci. 75:1119-1126.

Cassell, B. G., V. Adamec, and R. E. Pearson. 2003. Effect of incomplete pedigrees on estimates of inbreeding depression for days to first service and summit milk yield in Holsteins and Jerseys. J. Dairy Sci. 86:2967-2976.

Coffey, E. M., W. E. Winson, and R. E. Pearson. 1986. Potential of somatic cell concentration in milk as a sire selection criterion to reduce mastitis in dairy cattle. J. Dairy Sci. 69:2163-2172.

Ducrocq, V., and B. Besbes. 1993. Solution of multiple trait animal models with missing data on some traits. J. Anim. Breed. Genet. 110:81-92.

Emmanuelson, U., B. Danell, and J. Philipsson. 1988. Genetic parameters for clinical mastitis, somatic cell counts, and milk production estimated by multiple trait restricted maximum likelihood. J. Dairy Sci. 71:467.

Gengler, N., and C. Croquet. 2005. Standard errors of solutions in large scale mixed models, application to linear and curvilinear effects of inbreeding on production traits. J. Dairy Sci. 88(Suppl. 1):73. (Abstr.)

Gengler, N., T. Dusseldorf, G. R. Wiggans, J. R. Wright, and T. Druet. 2001a. Heterogeneity of (co)variance components for Jersey type traits. J. Dairy Sci. 84:1772.

Gengler, N., T. Dusseldorf, G. R. Wiggans, J. R. Wright, and T. Druet. 2001c. Multitrait genetic evaluation of Jersey type with inte- 
grated accounting for heterogeneous (co)variances. http://wwwinterbull.slu.be/bulletins/bulletin25/gengler.pdf Interbull Bull. 25:123-127.

Gengler, N., and P. Mayeres. 2003. Use of a weighted random regression test-day model to better relate observed somatic cell score to mastitis infection likelihood. http://www-interbull.slu.se/bulletins/bulletin31/Gengler.pdf Interbull Bull. 31:92-96.

Gengler, N., G. R. Wiggans, and J. R. Wright. 1999. Animal model genetic evaluation of type traits for five dairy cattle breeds. J. Dairy Sci. 82:1350.

Gengler, N., G. R. Wiggans, J. R. Wright, and T. Druet. 2001b. Simultaneous accounting for heterogeneity of (co)variance components in genetic evaluation of type traits. J. Dairy Sci. 84(Suppl. 1):247. (Abstr.)

Harville, D. A. 1979. Some useful representations for constrained mixed-model estimation. J. Am. Stat. Assoc. 74:200-206.

Henderson, C. R. 1974. General flexibility of linear model techniques for sire evaluation. J. Dairy Sci. 57:963.

Kearney, J. F., E. Wall, B. Villanueva, and M. P. Coffey. 2004. Inbreeding trends and application of optimized selection in the UK Holstein population. J. Dairy Sci. 87:3503-3509.

Lund, T., F. Miglior, J. C. M. Dekkers, and E. B. Burnside. 1994. Genetic relationships between clinical mastitis, somatic cell count, and udder conformation in Danish Holsteins. Livest. Prod. Sci. 39:243-251.

Meuwissen, T. H. E., and Z. Luo. 1992. Computing inbreeding coefficients in large populations. Genet. Sel. Evol. 24:305-313.

Miglior, F. 1994. Impact of inbreeding in dairy cattle. PhD Thesis. Department of Animal and Poultry Science. University of Guelph, ON, Canada.

Miglior, F., E. B. Burnside, and J. C. M. Dekkers. 1995. Non-additive genetic effects and inbreeding depression for somatic cell counts in Holstein cattle. J. Dairy Sci. 78:1168-1173.

Miglior, F., B. Szkotnicki, and E. B. Burnside. 1992. Analysis of levels of inbreeding and inbreeding depression in Jersey cattle. J. Dairy Sci. 75:1112-1118.

Misztal, I., T. J. Lawlor, and N. Gengler. 1997. Relationships among estimates of inbreeding depression, dominance and additive variance for linear traits in Holsteins. Genet. Sel. Evol. 29:319-326.

Mrode, R., G. J. T. Swanson, and M. F. Paget. 2004. Computing inbreeding coefficients and effects of inbreeding, heterosis and recombination loss on evaluations for lifespan and somatic cell count in the UK. http://www-interbull.slu.se/bulletins/bulletin32/ Mrode.pdf Interbull Bull. 32:109-112.

Russell, J. E. 1947. Old cattle prints. Country Life 101, 2622:704-706.

Smith, L. A., B. G. Cassell, and R. E. Pearson. 1998. The effects of inbreeding on the lifetime performance of dairy cattle. J. Dairy Sci. 81:2729-2737.

Thompson, J. R., R. W. Everett, and N. L. Hammerschmidt. 2000. Effects of inbreeding on production and survival in Holsteins. $\mathrm{J}$. Dairy Sci. 83:1856-1864.

Van Doormaal, B., F. Miglior, G. Kistemaker, and P. Brand. 2005 Genetic diversification of the Holstein breed in Canada and internationally. http://www.cdn.ca/committees/Apr2005/Diversification.pdf Accessed May 16, 2005.

VanRaden, P. M. 1992. Accounting for inbreeding and crossbreeding in genetic evaluation of large populations. J. Dairy Sci. 75:3136-3144

VanRaden, P. M. 2000. Net merit as a measure of lifetime profit. http://aipl.arsusda.gov/reference/nmcalc-2000.htm Accessed May $16,2005$.

VanRaden, P. M., and L. A. Smith. 1999. Selection and mating considering expected inbreeding of future progeny. J. Dairy Sci. 82:2771-2778.

VanRaden, P. M., and M. E. Tooker. 2004. Genetic base change for February 2005. http://aipl.arsusda.gov/reference/base2005.htm Accessed May 16, 2005.

Van Vleck, L. D. 1992. The revolution in statistical computing from least squares to DFREML. Proc. 41st Annual National Breeders Roundtable, St. Louis, MO. http://www.poultryscience.org/pba/ 1952-2003/1992/1992\%ZOVleck.pdf Accessed Mar. 22, 2006.

Weigel, K. A. 2001. Controlling inbreeding in modern breeding programs. J. Dairy Sci. 84(E. Suppl.):E177-E184.

Wiggans, G. R., P. M. VanRaden, and J. Zuurbier. 1995. Calculation and use of inbreeding coefficients for genetic evaluation of United States dairy cattle. J. Dairy Sci. 78:1584-1590.

Young, C. W., R. R. Bonczeck, and D. G. Johnson. 1988. Inbreeding of and relationship among registered Holsteins. J. Dairy Sci. $71: 1659$

Young, C. W., and A. J. Seykora. 1996. Estimates of inbreeding and relationship among registered Holstein females in the United States. J. Dairy Sci. 79:502-505. 